\title{
Perkinsus sp. infecting three important mollusks from Jaguaribe River estuary, Ceará, Brazil
}

\section{Perkinsus sp. infectando três importantes moluscos do estuário do Rio Jaguaribe, Ceará, Brasil}

\author{
Maximiano Pinheiro Dantas Neto ${ }^{1}$ (D); Rodrigo Maggioni² ${ }^{2}$; Luiz Fagner Ferreira Nogueira $^{2}$ (D); \\ Jamille Martins Forte ${ }^{2}$; Rubens Galdino Feijó ${ }^{3}$ (D); Rachel Costa Sabry ${ }^{1}$ (D) \\ ${ }^{1}$ Instituto Federal de Educação, Ciência e Tecnologia do Ceará, Aracati - CE, Brazil
${ }^{2}$ Universidade Federal do Ceará, Instituto de Ciências do Mar, Fortaleza - CE, Brazil
${ }^{3}$ Instituto Federal de Educação, Ciência e Tecnologia do Ceará, Acaraú - CE, Brazil
}

\section{ABSTRACT}

This work investigated the occurrence of Perkinsus sp. in clam Anomalocardia brasiliana, oyster Crassostrea sp. and mussel Mytella falcata from the Jaguaribe River estuary, northeastern Brazil. The collection of clam $(\mathrm{N}=300)$, oysters $(\mathrm{N}=300)$ and mussels $(\mathrm{N}=300)$ were carried out in the estuary of the Jaguaribe River, Ceará, in March and April (rainy season) and October (dry season) in 2017. The mollusks were measured in their major axis, open, and had their tissues submitted to tissue incubation techniques in Ray's fluid thioglycollate medium (RFTM), histology, real-time polymerase chain reaction (qPCR), PCR and sequencing. The RFTM assays showed Perkinsus sp. infecting the three mollusks investigated. The prevalence of infected clams was $1.33 \%$ in both sampling periods, oysters ranged from 2.66 (rainy season) to $8 \%$ (dry period), and mussels from $0 \%$ (dry period) to $51.33 \%$ (rainy season). The intensity of infection was very light to light in clams, very soft to severe in oysters and very soft to moderate in mussels. Histological analyses showed cells of Perkinsus sp. infecting the gills and connective tissue around the digestive gland of some individuals. The qPCR generated amplicons in all positive samples in RFTM, confirming the presence of Perkinsus sp., while the sequencing evidenced high similarity (99\%) with the species P. beihaiensis. In conclusion, the results obtained contribute to increasing knowledge about the occurrence of Perkinsus sp. in bivalve mollusks from northeastern Brazil.

Keywords: Bivalve. Disease. Perkinsus.

\section{RESUMO}

Foi investigada a ocorrência da infecção pelo protozoário Perkinsus sp. em berbigões Anomalocardia brasiliana, ostras Crassostrea sp. e mexilhões Mytella falcata do estuário do Rio Jaguaribe, Nordeste do Brasil. As colheitas dos berbigões $(\mathrm{N}=300)$, ostras $(\mathrm{N}=300)$ e mexilhões $(\mathrm{N}=300)$ foram realizadas no estuário do Rio Jaguaribe, Ceará, nos meses de março e abril (período chuvoso) e outubro (período seco) de 2017. Os moluscos foram medidos em seu maior eixo, abertos e os seus tecidos foram submetidos às técnicas de incubação de tecidos em meio fluido de tioglicolato de Ray (RFTM), histologia, reação em cadeia da polimerase em tempo real (qPCR), PCR e sequenciamento. Os ensaios de RFTM evidenciaram Perkinsus sp. infectando os três moluscos investigados. A prevalência de berbigões infectados foi de 1,33\% em ambos os períodos de amostragem, a de ostras variou de 2,66 (período chuvoso) a $8 \%$ (período seco) e a de mexilhões de $0 \%$ (período seco) a 51,33\% (período chuvoso). A intensidade de infecção apresentou-se muito leve a leve em berbigões, muito leve à severa nas ostras e muito leve à moderada nos mexilhões. As análises histológicas mostraram células de Perkinsus sp. infectando as brânquias e tecido conjuntivo em torno da glândula digestiva de alguns indivíduos. A qPCR gerou amplicons em todas as amostras positivas em RFTM, confirmando a presença de Perkinsus sp., enquanto o sequenciamento mostrou alta similaridade (99\%) com a espécie P. beihaiensis. Em conclusão, os resultados do presente estudo contribuem para ampliar o conhecimento sobre a ocorrência de Perkinsus sp. em moluscos bivalves do Nordeste do Brasil.

Palavras-chave: Bivalve. Enfermidade. Perkinsus. 


\section{Correspondence to:}

Maximiano Pinheiro Dantas Neto

Instituto Federal de Educação Ciência e Tecnologia do Ceará

Rodovia CE-040, Km 137,1 s/n, Aeroporto

CEP: 62930-000, Fortaleza - CE, Brazil

e-mail: maxfloyd@hotmail.com

Received: May 24, 2019

Approved: October 07, 2019

How to cite: Dantas Neto MP, Maggioni R, Nogueira LFF, Forte JM, Feijó RG, Sabry RC. Perkinsus sp. infecting three important mollusks from Jaguaribe River estuary, Ceará, Brazil. Braz J Vet Res Anim Sci. 2020;57(1):e158316. https://doi.org/10.11606/issn.1678-4456.bjvras.2020.158316

\section{Introduction}

Bivalve mollusks are distributed in different regions of the world, among them, estuarine regions along the Brazilian coast, therefore, constituting important fishing resources. These animals can be infected by protozoa belonging to the genus Perkinsus, which has two species of mandatory notification to OIE, P. marinus and P. olseni, which have been associated with severe economic losses (Villalba et al., 2004). Perkinsus sp. was first identified in 1950 in the oyster Crassostrea virginica in the United States (Mackin et al., 1950), but only in 2005 a representative of this genus (Perkinsus olseni) was registered in South America, infecting the bivalve Pitar rostrata in Uruguay (Cremonte et al., 2005).

In Brazil, Perkinsus sp. was reported for the first time in the native oyster Crassostrea rhizophorae from the Pacoti River estuary, Ceará state, in the country's northeastern region (Sabry et al., 2009). Later, another study indicated that the species that was infecting the oysters from this estuary was P. beihaiensis (Sabry et al., 2013). Since then, other studies have reported the occurrence of Perkinsus sp. in oysters of the genus Crassostrea from several regions (Brandão et al., 2013; Dantas et al., 2015; Luz et al., 2018; Scardua et al., 2017). It is worth noting the record, in 2016, of the species $P$. chesapeaki, detected for the first time in South America, infecting oysters from the Jaguaribe River estuary, Ceará (Dantas et al., 2016). In Veneridae, in Brazil's northeastern region, only one study recorded the occurrence of $P$. beihaiensis infecting the clam Anomalocardia brasiliana (Ferreira et al., 2015).

Over the years, with the intensification of the studies, P. marinus was found infecting oysters from estuaries of the states of Paraíba (Silva et al., 2013), Sergipe (Silva et al., 2014), Ceará (Dantas, 2015) and Bahia (Pinto et al.,
2016) and, recently, in C. gigas from cultivation and C. gasar (native) from the State of Santa Catarina, southern Brazil (Cunha et al., 2019), while P. olseni was detected in C. gasar from the São Francisco River estuary, Sergipe (Silva et al., 2014). Despite advances of the research in the region, knowledge about the impact of this protozoan on the host is still little understood.

In the estuaries of the Ceará state, bivalve mollusks are exploited in an extractive way, but the region is promising for future cultivations, requiring, therefore, constant monitoring of native populations. As observed, the occurrence of Perkinsus sp. is more advanced in oysters, requiring more studies that assess other bivalves affected by this protozoan.

In this way, this work investigated the occurrence of Perkinsus sp. in three species of important mollusks from the estuary of Jaguaribe River, Ceará, Brazil.

\section{Material and Methods}

In 2017, during the months of March and April (rainy season) and October (dry season) in northeastern Brazil, specimens of clam A. brasiliana $(\mathrm{N}=300)$, oysters Crassostrea sp. $(\mathrm{N}=300)$ and mussels $M$. falcata $(\mathrm{N}=300)$ were collected from the sandy/muddy substrate and the roots of the red mangrove Rhizophora mangle from the Jaguaribe River estuary, Ceará State $\left(04^{\circ} 27^{\prime} 39.21^{\prime \prime}\right.$, $\left.37^{\circ} 47^{\prime} 31.68^{\prime \prime} \mathrm{W}\right)$. In the laboratory, the animals were measured on their largest axis (Galtsoff, 1964), open, and had their tissues submitted to incubation techniques in Ray's fluid thioglycollate medium (RFTM), histology, real-time polymerase chain reaction - qPCR, PCR and sequencing, to investigate the presence and/or absence of Perkinsus sp. In the rainy season, the average size of the animals was $2.26 \mathrm{~cm} \pm 0.12 ; 6.0 \mathrm{~cm} \pm 0.63$ and $3.43 \mathrm{~cm} \pm 0.20$, for clam, oysters, and mussels, respectively. In the dry period, the average size was $2.35 \mathrm{~cm} \pm 0.13$ (clam), $6.55 \mathrm{~cm} \pm 0.98$ (oysters), and $3.27 \mathrm{~cm} \pm 0.22$ (mussels).

\section{Tissue incubation in RFTM}

Two gill lamelae and the rectum of each animal were incubated in RFTM (Ray, 1966) containing antibiotics (penicillin/streptomycin) and antifungal (Nystatin) for 7 days in darkness and at room temperature. After the incubation period, the fragments of tissues were macerated on a histological slide and stained with 3\% iodine solution. The preparation was observed under light microscope as to the presence of spherical, blue or black-bluish hypnospores of the genus Perkinsus. The intensity of the infection was estimated according to the Mackin scale (Ray, 1954), modified by Sabry et al. (2009). 


\section{Histology}

A transversal section of 30 animals/species/period of the year, containing gills, gonads and digestive gland was excised and fixed in Davidson's solution (Shaw \& Battle, 1957 ) for $24 \mathrm{~h}$. After inclusion in histological paraffin at $60^{\circ} \mathrm{C}$, sections of $5 \mu \mathrm{m}$ were prepared and stained with Harris hematoxylin and eosin (H\&E) (Howard et al., 2004) and the tissues analyzed under light microscopy as to the presence of Perkinsus sp. and tissue changes. The prevalence of Perkinsus was defined as the number of infected animals divided by the total number of animals analyzed (Bush et al., 1997).

\section{Detection of Perkinsus sp. by polymerase chain reaction ( $q P C R$ and $P C R$ )}

All animals had their gill tissues preserved in 95\% alcohol for real-time PCR analysis (qPCR) but only 97 positive animals in the RFTM assays were subjected to this technique. Total genomic DNA extraction was performed with a DNAzol ${ }^{\circledR}$ kit (Invitrogen) following the manufacturer's instructions. After that, the extracted DNA was quantified in a Nanodrop 2000 spectrophotometer (Thermo Scientific, Waltham, MA, USA) at $260 \mathrm{~nm}$. DNA extracted from Perkinsus beihaiensis cells was used as a positive control. For negative control, the DNA was replaced by nuclease-free water.

A pair of primers for real-time PCR assays was designed by sequence alignment of the region ITS of Perkinsus sp. using the software Geneious R11. The qPCR reactions, using the ABI 7500 Real Time PCR System (Applied Biosystems $^{\circledR}$ ) platform, were made in a final volume of $10 \mu \mathrm{L}$ containing $5 \mu \mathrm{L}$ of Platinum ${ }^{\circledR}$ SYBR $^{\circledR}$ Green qPCR SuperMix-UDG (Invitrogen ${ }^{\circledR}$ ), $0.3 \mu \mathrm{L}$ of the primer Perkinsus (RT) -F (TGCCTCGGCTCGAGAATC), $0.3 \mu \mathrm{L}$ of the Perkinsus primer (RT) -R (TTCTGCAAATCGCAGTGCTT), $0.2 \mu \mathrm{L}$ ROX reference dye, $1 \mu \mathrm{L}$ DNA and $3.2 \mu \mathrm{L}$ of ultra-pure water (Invitrogen ${ }^{\circledR}$ ). The thermocycling conditions used were $50{ }^{\circ} \mathrm{C} / 2 \mathrm{~min}, 95^{\circ} \mathrm{C} / 2 \mathrm{~min}$, followed by 40 cycles of $95^{\circ} \mathrm{C} / 15 \mathrm{~s}$ and $60^{\circ} \mathrm{C} / 30 \mathrm{~s}$.

PCR reactions were performed in a final volume of $25 \mu \mathrm{L}$ containing 50-100ng template DNA, $1 \mathrm{x}$ PCR buffer, $1.5 \mathrm{mM} \mathrm{MgCl} 2,0.2 \mathrm{mM}$ of each dNTP, $0.8 \mathrm{mM}$ of the primers Perk ITS 85 (CCGCTTTGTTTGGATCCC) and Perk ITS 750 (ACATCAGGCCTTCTAATGATG) (Casas et al., 2002) and 1 unit of Taq DNA polymerase (Invitrogen). The protocol included a DNA denaturation at $94{ }^{\circ} \mathrm{C}$ for $10 \mathrm{~min}$, and 35 cycles of amplification at $94^{\circ} \mathrm{C}(1 \mathrm{~min}), 55^{\circ} \mathrm{C}(1 \mathrm{~min})$ and $72{ }^{\circ} \mathrm{C}(1 \mathrm{~min})$, followed by a final extension at $72{ }^{\circ} \mathrm{C}$ for $10 \mathrm{~min}$. PCR products were separated by electrophoresis in $1.5 \%$ TAE agarose gel and stained with Blue Juice ${ }^{\mathrm{TM}}$.

\section{DNA sequencing}

The direct sequencing for PCR products was carried out for positive samples. Reactions were performed using the sequencing kit BigDye ${ }^{\mathrm{mx}}$ Terminator v3.1 Cycle Sequencing (Applied Biosystems $\mathrm{s}^{\mathrm{nx}}$ ). For each sequencing reaction, $2 \mu \mathrm{L}$ of BigDye; $1 \mu \mathrm{L}$ of proprietary $5 \mathrm{x}$ buffer, 0.5 to $2.5 \mu \mathrm{L}$ of purified DNA, $0.32 \mu \mathrm{L}$ primer (3.2pmol) and enough water for a total reaction volume of $10 \mu \mathrm{L}$ were used. All samples were sequenced in the forward and reverse directions.

The sequencing reaction was performed in a Techne Flexigene ${ }^{\circledR}$ PCR Thermal Cycler under the following thermocycling conditions: initial denaturation at $96^{\circ} \mathrm{C}$ for $4 \mathrm{~min}$, followed by 25 cycles $\left(96^{\circ} \mathrm{C}\right.$ for $10 \mathrm{sec}, 50^{\circ} \mathrm{C}$ for $5 \mathrm{sec}, 60^{\circ} \mathrm{C}$ for $\left.4 \mathrm{~min}\right)$. The purification of the products of the sequencing reaction was carried out by adding $40 \mu \mathrm{L}$ of isopropanol (65\%) per reaction. At the end, the samples were resuspended in formamide, denatured at $95^{\circ} \mathrm{C}$ for $5 \mathrm{~min}$ and read on the ABI 3500 automatic capillary sequencing platform (Applied Biosystems).

The phylogenetic tree was produced through the neighbor-joining algorithm (Saitou \& Nei, 1987), using the distance of model Kimura 2 parameters (Kimura, 1980), missing pair deletion and 1,000 bootstrap replicates (Felsenstein, 1985).

\section{Results and Discussion}

The RFTM assays revealed the presence of hypnospores of Perkinsus sp. infecting the tissues of the clams (4/300), oysters (16/300) and mussels (77/300) in the rainy and dry period. The enlarged and spherical cells presented a size ranging from 5-55 $\mu \mathrm{m}$ in diameter, stained in black by iodine solution (Figure 1), as described by Choi \& Park

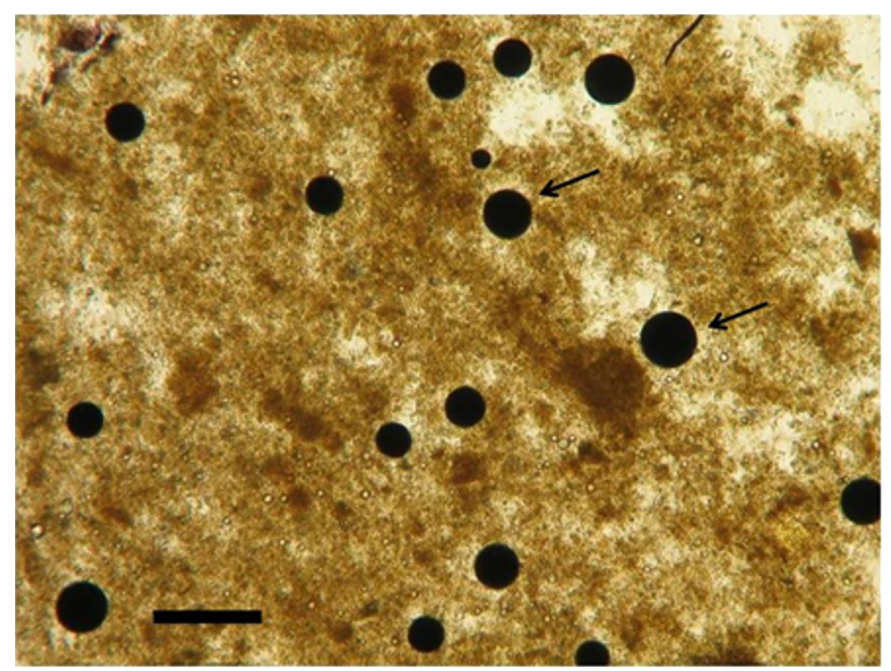

Figure 1 - Hypnospores of Perkinsus sp. (arrows) in gill tissues of Crassotrea sp. after incubation in RFTM and stained with iodine solution. Scale bar $=20 \mu \mathrm{m}$. 
(2010) and similar to those observed in other mollusks from the Brazilian coast (Brandão et al., 2013; Queiroga et al., 2015; Sabry et al., 2009).

The average prevalence of infected clams was $1.33 \%$ in both sampling periods, oysters ranged from $2.66 \%$ (rainy season) to $8 \%$ (dry season) and mussels from $0 \%$ (dry season) to $51.33 \%$ (rainy season). In the rainy season, the prevalence of Perkinsus sp. was low, except for that observed in M. falcata, which was considered moderate. The low prevalence observed in A. brasiliana of this study (1.33\%) was lower than that observed in the same species (14.7\%) from the estuary of Timonha River, Ceará (Ferreira et al., 2015).

In recent years, the prevalence of Perkinsus observed in oysters from different regions of the country has varied considerably and, although the value found in this study (8\%) has been lower than that recorded in oysters from that same estuary in 2015 (17.3\%) and in oysters from Carnaubeira River in Maranhão (10.6\%), the same was higher than the values recorded in oysters from the estuaries of the Rivers Camurupim, in Piauí (5.3\%) (Dantas et al., 2015) and Pacoti, in Ceará, in 2009 and 2010 (Sabry et al., 2013). In other states of the northeastern region, the prevalence of Perkinsus recorded in the RFTM assays has been higher than the values mentioned above (Luz et al., 2018; Queiroga et al., 2015; Scardua et al., 2017; Silva et al., 2016). In the present study, the infection intensity ranged from very light to light (clams), very light to severe (oysters) and very light to moderate (mussels).

Histological analyses in the three species of mollusks showed the presence of Perkinsus trophozoites in the gills and connective tissue around the digestive gland. The trophozoites were spherical and with a vacuole occupying the most of the cytoplasm (Figure 2). In the rainy season, positive animals in RFTM and that were diagnosed by histology, presented prevalence of $10 \%, 10 \%$ and $23.3 \%$, for A. brasiliana, Crassostrea sp. and M. falcata, respectively. In the dry period, the highest prevalence of Perkinsus sp. was observed in oysters (30\%). In general, histological analyses revealed few trophozoites in the tissues, without damage to the epithelium of the digestive tract or to the gill tissue, without hemocytic infiltration and phagocytosed trophozoites. These results were similar to those found by Sabry et al. (2013), which did not observe any alteration in infected tissues of $C$. rhizophorae. On the other hand, Perkinsus cells were observed phagocytosed in the tissues of Crassostrea gasar, indicating a defense response of the host (Queiroga et al., 2015). Also, recent studies with oysters from Bahia showed that the animals infected with P. beihaiensis presented hemocytes infiltration and tissue

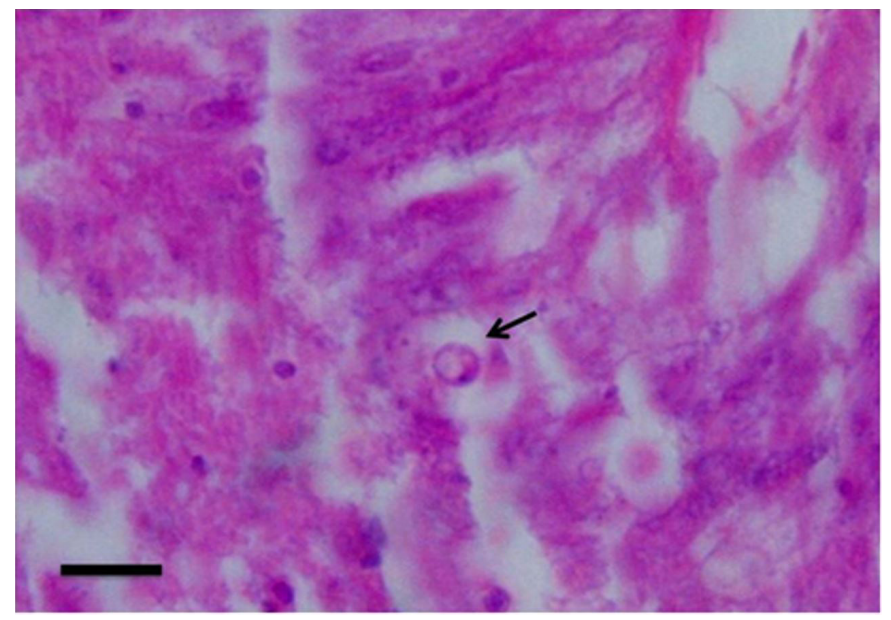

Figure 2 -Perkinsus sp. (arrow) infecting the connective tissue of Anomalocardia brasiliana, collected in the estuary of the Jaguaribe River, Ceará. Scale bar $=10 \mu \mathrm{m}$.

disorganization (Luz \& Boehs, 2016; Luz et al., 2018). As can be observed, the effects of infection by this pathogen on the host need to be better understood.

From the 97 samples positive for Perkinsus in RFTM assays and submitted to real-time PCR analysis (qPCR) for confirmation, 74 cases were confirmed. In this study the pair of primers proposed for the detection of Perkinsus sp. by qPCR, produced amplified fragments of expected size in all positive samples, confirming the presence of Perkinsus sp. Analyses of fragments from the region ITS of Perkinsus amplified by qPCR resulted in amplicons with approximately $70 \mathrm{bp}$, confirming 76.29\% (74/97) of RFTM-positive animals. As observed, 23 animals showed a negative result in qPCR, suggesting the low intensity of Perkinsus cells in the infected tissues or they did not contain cells of the pathogen. Differences in results between diagnostic techniques have been associated with low amount of tissue and low infection intensity (Brandão et al., 2013; Sabry et al., 2009, 2013) and also the use of different organs in the techniques used for the diagnosis (Luz et al., 2018). In another study, Dantas et al. (2016) found different results between the techniques of conventional PCR and qPCR, confirming the greater sensitivity of the latter for detection of Perkinsus sp.

The result of product sequencing of the PCR-positive sample reached the coverage of 616bp of the gene region of the ribosomal RNA, including the ITS1 partial region, the full region 5.8S rRNA, and the ITS2 partial region. These sequences presented homologies of $99 \%$ identity with the sequences of $P$. beihaiensis from Brazil (Cunha et al., 2019; Ferreira et al., 2015; Queiroga et al., 2015; Sabry et al., 2009), from China (Moss et al., 2008) and from Panama (Pagenkopp Lohan et al., 2016). 


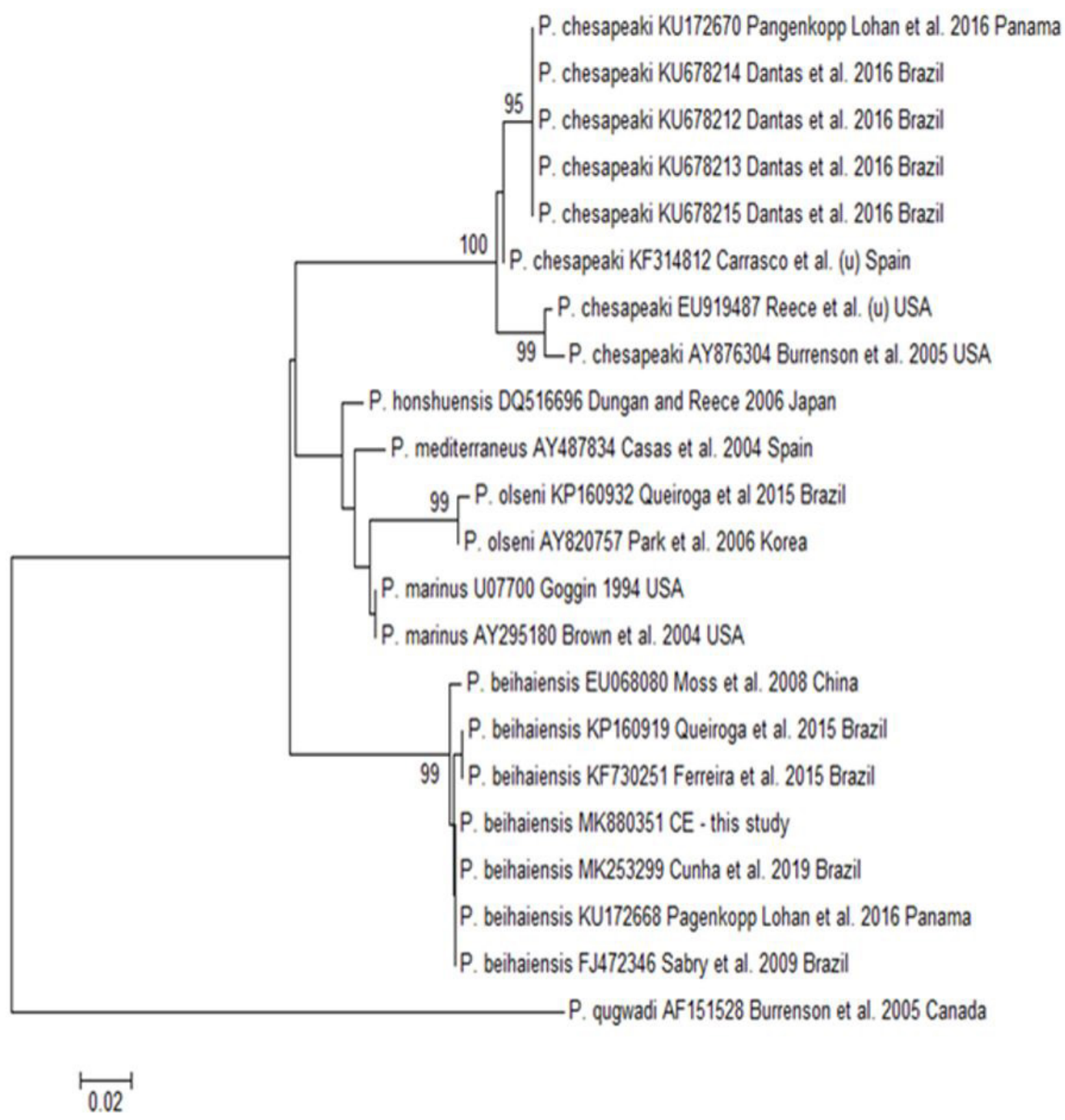

Figure 3 -Neighbor-Joining tree based on the method of distance Kimura 2 parameters (Kimura, 1980), including sequences from the Genbank database. Numbers plotted in the branches represent bootstrap support after 1,000 replicates (Felsenstein, 1985). The rate variation between sites was modeled with a gamma distribution (shape parameter=1). Only values greater than 80 were plotted.

The neighbor-joining tree grouped the sequence of this study (MK880351) into a clade including all sequences classified as $P$. beihaiensis (Figure 3), indicating a close phylogenetic relationship between the sequences of Perkinsus sp. from Brazil (identified in previous studies), China, and Panama. Therefore, the results strongly suggest that the sequence of the gene region studied in the host Crassostrea sp. is the species P. beihaiensis.

The present work confirmed once again the presence of P. beihaiensis in the oyster Crassostrea sp. and expanded the occurrence of Perkinsus sp. in Anomalocardia brasiliana and Mytella falcata from the Jaguaribe River estuary, Ceará.

\section{Conflict of Interest}

The authors state that they have no conflicts of interest to declare.

\section{Ethics Statement}

The authors work in accordance with the guidelines of the COPE (Committee on Publication Ethics). In this way, they declare that the contribution is original and unpublished, the referred manuscript is not being evaluated for publication in another journal and that the text does not fit in the situations described in editorial policy on plagiarism.

\section{Acknowledgements}

The authors are grateful to National Council for Scientific and Technological Development (CNPq) and Cearense Foundation to Support Scientific and Technological Development (FUNCAP) for the DCR scholarship to Dr. Maximiano Pinheiro Dantas Neto. 


\section{References}

Brandão RP, Boehs G, Sabry RC, Ceuta LO, Luz MS, Queiroga FR, Silva PM. Perkinsus sp. infecting oyster Crassostrea rhizophorae on the coast of Bahia, Brazil. J Invertebr Pathol. 2013;112(2):138-41. http://dx.doi.org/10.1016/j. jip.2012.11.003. PMid:23201453.

Bush AO, Lafferty AD, Lotz JM, Shostak AW. Parasitology meets ecology on its own terms: margolis et al. revisited. J Parasitol. 1997;83(4):575-83. http://dx.doi.org/10.2307/3284227. PMid:9267395.

Casas SM, Villalba A, Reece KS. Study of perkinsosis in the carpet shell clam Tapes decussatus in Galicia (NW Spain). I. Identification of the aetiological agent and in vitro modulation of zoosporulation by temperature and salinity. Dis Aquat Organ. 2002;50(1):51-65. http://dx.doi. org/10.3354/dao050051. PMid:12152905.

Choi K, Park K. Review on the protozoan parasite Perkinsus olseni (Lester and Davis, 1981) infection in Asian waters. In Ishimatsu A, Lie HJ, editors. Coastal environmental and ecosystem, issues east China sea. Japan: TERRAPUB; 2010.p. 269-81.

Cremonte F, Balseiro P, Figueras A. Occurrence of Perkinsus olseni (Protozoa: Apicomplexa) and other parasites in the venerid commercial clam Pitar rostrata from Uruguay, southwestern Atlantic coast. Dis Aquat Organ. 2005;64(1):8590. http://dx.doi.org/10.3354/dao064085. PMid:15900692.

Cunha ACL, Pontinha VA, Castro MAM, Sühnel S, Medeiros SC, Luz AMM, Harakava R, Tachibana L, Mello DF, Danielli NM, Dafre AL, Magalhães ARM, Mouriño JL. Two epizootic Perkinsus spp. events in commercial oyster farms at Santa Catarina, Brazil. J Fish Dis. 2019;42(3):45563. http://dx.doi.org/10.1111/jfd.12958.

Dantas MP No. Patógenos na ostra Crassostrea rhizophorae de estuários da costa setentrional do Nordeste brasileiro [tese]. Fortaleza: Instituto de Ciências do Mar, Universidade Federal do Ceará; 2015.

Dantas MP No, Sabry RC, Ferreira LP, Romão LS, Maggioni R. Perkinsus sp. infecting the oyster Crassostrea rhizophorae from estuaries of the septentrional Northeast, Brazil. Braz J Biol. 2015;75(4):1030-4. http://dx.doi.org/10.1590/15196984.06314. PMid:26675922.

Dantas MP No, Gesteira TCV, Sabry RC, Feijó RG, Forte JM, Boehs G, Maggioni R. First record of Perkinsus chesapeaki infecting Crassostrea rhizophorae in South America. J Invertebr Pathol. 2016;141:53-6. http://dx.doi.org/10.1016/j. jip.2016.10.007. PMid:27810288.

Felsenstein J. Confidence limits on phylogenies: an approach using the bootstrap. Evolution. 1985;39(4):783-91. http:// dx.doi.org/10.1111/j.1558-5646.1985.tb00420.x.

Ferreira LP, Sabry RC, Silva PM, Gesteira TCV, Romão LS, Paz MP, Feijó RG, Dantas MP No. First report of Perkinsus beihaiensis in wild clams Anomalocardia brasiliana (Bivalvia: Veneridae) in Brazil. Exp Parasitol. 2015;150:67-70. http:// dx.doi.org/10.1016/j.exppara.2014.07.012. PMid:25088443.

Galtsoff PS. The American Oyster Crassostrea virginica Gmelin. Washington: United States Government Printing Office; 1964. 480 p. Fishery Bulletin: 64.

Howard DW, Lewis EJ, Keller BJ, Smith CS. Histological techniques for marine bivalve mollusks and crustaceans. Oxford, MD: National Oceanic and Atmospheric Administration; 2004, 218 p. NOAA Technical Memorandum: NOSNCCOS5.

Kimura M. A simple method for estimating evolutionary rates of base substitutions through comparative studies of nucleotide sequences. J Mol Evol. 1980;16(2):111-20. http:// dx.doi.org/10.1007/BF01731581. PMid:7463489.

Luz MSA, Boehs G. Perkinsus beihaiensis infectando a ostra Crassostrea rhizophorae em cultivo e em estoque natural na Baía de Camamu, Bahia, Brasil. Braz J Vet Res Anim Sci. 2016;53(2):191-8. http://dx.doi.org/10.11606/issn.16784456.v53i2p191-198.

Luz MSA, Carvalho FS, Oliveira HC, Boehs G. Perkinsus beihaiensis (Perkinsozoa) in oysters of Bahia State, Brazil. Braz J Biol. 2018;78(2):289-95. http://dx.doi.org/10.1590/15196984.07016. PMid:28832834.

Mackin JG, Owen HM, Collier A. Preliminary note on the occurrence of a new protistan parasite, Dermocystidium marinum n. sp., in Crassostrea virginica (Gmelin). Science. 1950;111(2883):328-9. http://dx.doi.org/10.1126/ science.111.2883.328. PMid:17791737.

Moss JA, Xiao J, Dungan CF, Reece KS. Description of Perkinsus beihaiensis n. sp., a new Perkinsus sp. parasite in oysters of Southern China. J Eukaryot Microbiol. 2008;55(2):117-30. http://dx.doi.org/10.1111/j.15507408.2008.00314.x. PMid:18318865. 
Pagenkopp Lohan K, Hill-Spanik K, Torchin M, AguirreMacedo L, Fleischer R, Ruiz G. Richness and distribution of tropical oyster parasites in two oceans. Parasitology. 2016;143(9):1119-32. http://dx.doi.org/10.1017/ S0031182015001900. PMid:27263626.

Pinto TR, Boehs G, Pessoa WFB, Luz MSA, Costa H. Detection of Perkinsus marinus in the oyster Crassostrea rhizophorae in southern Bahia by proteomic analysis. Braz J Vet Res Anim Sci. 2016;53(4):1-4. http://dx.doi. org/10.11606/issn.1678-4456.bjvras.2016.84551.

Queiroga FR, Vianna RT, Vieira CB, Farias ND, Silva PM. Parasites infecting the cultured oyster Crassostrea gasar (Adanson, 1757) in Northeast Brazil. Parasitology. 2015;142(6):756-66. http://dx.doi.org/10.1017/ S0031182014001863. PMid:25553815.

Ray SM. Biological studies of Dermocystidium marinum, a fungus parasite of oysters. Houston: Rice Institute; 1954. (Rice Institute pamphlet. Special issue. Monograph in Biology).

Ray SM. A review of the culture method for detecting Dermocystidium marinum, with suggested modifications and precautions. Proc Natl Shellfish Assoc. 1966;54:55-69.

Sabry RC, Gesteira TCV, Magalhães ARM, Barracco MA, Guertler C, Ferreira LP, Vianna RT, Silva PM. Parasitological survey of mangrove oyster, Crassostrea rhizophorae, in the Pacoti River Estuary, Ceará, State. J Invertebr Pathol. 2013;112(1):24-32. http://dx.doi.org/10.1016/j.jip.2012.10.004. PMid:23147104.

Sabry RC, Rosa RD, Magalhães AR, Barracco AM, Gesteira TCV, Silva PM. First report of Perkinsus sp. infecting mangrove oysters Crassostrea rhizophorae from the Brazilian coast. Dis Aquat Organ. 2009;88(1):13-23. http://dx.doi. org/10.3354/dao02136. PMid:20183961.

Saitou N, Nei M. The neighbor-joining method: a new method for reconstructing phylogenetic trees. Mol Biol Evol. 1987;4(4):406-25. http://dx.doi.org/10.1093/oxfordjournals. molbev.a040454. PMid:3447015.
Scardua MP, Vianna RT, Duarte SS, Farias ND, Correia MLD, Santos HTAD, Silva PMD. Growth, mortality and susceptibility of oyster Crassostrea spp. to Perkinsus spp. infection during on growing in northeast Brazil. Rev Bras Parasitol Vet. 2017;26(4):401-10. http://dx.doi.org/10.1590/ s1984-29612017061. PMid:29160355.

Shaw BL, Battle HI. The gross and microscopic anatomy of the digestive tract of the oyster Crassostrea virginica (Gmelin). Can J Zool. 1957;35(3):325-47. http://dx.doi. org/10.1139/z57-026.

Silva PM, Costa CP, Araújo JPB, Queiroga FR, Wainberg AA. Epizootiology of Perkinsus sp. in Crassostrea gasar oysters in polyculture with shrimps in northeastern Brazil. Rev Bras Parasitol Vet. 2016;25(1):37-45. http://dx.doi. org/10.1590/S1984-29612016011. PMid:27007244.

Silva PM, Scardua MP, Vianna RT, Mendonça RC, Vieira CB, Dungan CF, Scott GP, Reece KS. Two Perkinsus spp. infect Crassostrea gasar oysters from cultured and wild populations of the Rio São Francisco estuary, Sergipe, northeastern Brazil. J Invertebr Pathol. 2014;119:62-71. http://dx.doi.org/10.1016/j.jip.2014.04.005. PMid:24780219.

Silva PM, Vianna RT, Guertler C, Ferreira LP, Santana LN, Fernández-Boo S, Ramilo A, Cao A, Villalba A. First report of the protozoan parasite Perkinsus marinus in South America infecting mangrove oysters Crassostrea rhizophorae from the Paraiba River (NE, Brazil). J Invertebr Pathol. 2013;113(1):96-103. http://dx.doi.org/10.1016/j. jip.2013.02.002.

Villalba A, Reece KS, Camino Ordás M, Casas SM, Figueras A. Perkinsosis in mollusks: a review. Aquat Living Resour. 2004;17(4):411-32. http://dx.doi.org/10.1051/alr:2004050.

Financial Support: This research was funded by CNPq/FUNCAP under the process DCR-024-01724.01.00/15. 